It must be emphasized, however, that fission products were present on the days in question only in the normal daily average quantities and they did not show any activity peak. If we assume that tungsten has not been used in weapons in large quantities for special purposes, but simply as a component of the devices, the absence of relevant fission product activity peaks in connexion with the ${ }^{181} \mathrm{~W}$ and ${ }^{185} \mathrm{~W}$ present in the atmosphere would lead us to suppose that the nuclear devices were extremely clean. In this connexion we should point out that an underground nuclear test in the US Plowshare programme on December 8, 1968, produced two small radioactive clouds.

L. De Franceschi

A. Gentili

G. Gremigni

P. GUIDI

Servizio di Fisica Sanitaria,

Centro Applicazioni Militari

Energia Nucleare (CAMEN),

San Piero a Grado (Pisa), Italy.

Received March 4; revised April 22, 1969.

${ }^{2}$ Lockhart, L. B., Patterson, R. L., Saunders, A. W., and Black, R. W., Science, 132, 154 (1960).

\section{Lead-210 Production by Nuclear Devices: 1946-1958}

THE possible production of ${ }^{210} \mathrm{~Pb}$ during weapons testing by the reaction ${ }^{208} \mathrm{~Pb}(2 \mathrm{n}, \gamma){ }^{210} \mathrm{~Pb}$ was suggested by Peirson et al. ${ }^{1}$, who observed unusually high ratios of ${ }^{210} \mathrm{~Pb}$ in tropospheric air in 1962 and 1963 , and by Jaworowski ${ }^{2}$, who reported increased ${ }^{210} \mathrm{~Pb}$ concentrations in lichens and deer antlers in 1958-59 and 1962-63. On the other hand, Bhandari et al. ${ }^{3}$ and Crozaz ${ }^{4}$ found no corresponding increase in the amount of this isotope in air or glaciers, and $\mathrm{Krey}^{5}$ reported no unusually high levels of ${ }^{210} \mathrm{~Pb}$ in the stratosphere in 1966 . Resolution of this conflict is important because it has been postulated ${ }^{6}$ that nuclear devices used in excavating a canal in Central America would produce ${ }^{210} \mathrm{~Pb}$ in amounts comparable with ${ }^{90} \mathrm{Sr}-{ }^{-90} \mathrm{Y}$ as a radiological contaminant.

If ${ }^{210} \mathrm{~Pb}$ is produced in significant amounts during nuclear or thermonuclear explosions, it would be present at former test sites at Bikini and Eniwetok Atolls. The presence there of ${ }^{203} \mathrm{Bi}$ (ref. 7) probably formed by reactions such as ${ }^{207} \mathrm{~Pb}(\mathrm{p}, \mathrm{n}),{ }^{207} \mathrm{Bi}$ or ${ }^{206} \mathrm{~Pb}(\mathrm{p}, \gamma),{ }^{207} \mathrm{Bi}$ rather than by the ${ }^{209} \mathrm{Bi}(\mathrm{n}, 3 \mathrm{n}),{ }^{207} \mathrm{Bi}$ reaction, suggests that stable lead was present in shielding or structures adjacent to the nuclear devices. I therefore determined the ${ }^{210} \mathrm{~Pb}$ content of soil and sediment samples from areas of high radioactivity in the Pacific Proving Ground and, for comparison, samples from areas of the Pacific with negligible fall-out. Three of the samples contained ${ }^{207} \mathrm{Bi}$. Biological samples were not included in this study because the natural levels of ${ }^{210} \mathrm{~Pb}$ and ${ }^{210} \mathrm{Po}$ are not well established in tropical biota ${ }^{8}$; therefore, results would be equivocal, for marine organisms concentrate both ${ }^{210} \mathrm{~Pb}$ and ${ }^{210} \mathrm{Po}$.

The samples were taken from locations contaminated with local or intermediate fall-out except for those from Japtan Islet and Palmyra Island. The most radioactive samples were sediments taken from craters produced by test detonations. The soil samples from Kabelle Islet, Rongelap Atoll, were contaminated with fall-out from a thermonuclear device detonated at Bikini Atoll, 80 miles to the west, in March 1954. Gamma-dose rates three feet above the ground at Kabelle Islet were about $20 \mathrm{Rh}^{-1}$ on $\mathrm{D}+1$.

The naturally occurring concentrations of ${ }^{210} \mathrm{~Pb}$ in the island soils and sediments can be estimated from published data. Broecker ${ }^{9}$ measured the ${ }^{226} \mathrm{Ra}$ content of cores drilled at Eniwetok Atoll. Surface samples contained
Table 1. LEAD-210 IN BELECTED ATOLL SAMPLES Collec- Collec- ${ }^{210} \mathrm{~Pb}$ date $\operatorname{tion}(\mathrm{d} / \mathrm{m} / \mathrm{g} / \mathrm{dry}$

Location
Bikini Atoll
Bikini Lagoon
Aomen-Yurochi Islet
Aomen-Yurochi Islet
Bokonejien Islet
Bokonejien Islet
Bokonejien Islet
Namu Islet
Eniwetok Atoll
Japtan Islet
Elugelab Islet
Belle Islet
Belle Islet
Rongelap Atoll
Kabelle Islet
Kabelle Islet
Kabelle Islet
Palmyra Island
Sample $1949 \quad 0-12 \quad 6 \cdot 4 \pm 0 \cdot 10$ Sediment Sedim
Soil
Soil Soil Crater sediment Crater sediment Soil Soil Soil 196
196
196
196
196
196

195
196
195
19 Soil
Soil
Soil
Soil

$\begin{array}{cc}0-12 & 6 \cdot 4 \pm 0 \cdot 10 \\ 0-1 & 2 \cdot 7 \pm 0 \cdot 05 \\ 0-3 & 2 \cdot 0 \pm 0.05 \\ 0-12 & 4 \cdot 5 \pm 0 \cdot 07 \\ 0-12 & 4 \cdot 1 \pm 0.05 \\ 0-12 & 3 \cdot 3 \pm 0.04 \\ 13-16 & 0.5 \pm 0.02 \\ & \\ 0-1 & 2 \cdot 4 \pm 0.05 \\ 0-12 & 3 \cdot 8 \pm 0.06 \\ 0-3 & 0 \cdot 7 \pm 0.03 \\ 0-3 & 0.4 \pm 0.02 \\ & \\ 0-0.6 & 4 \cdot 3 \pm 0.08 \\ 0 \cdot 6-1.2 & 1 \cdot 4 \pm 0.04 \\ 0-8 & 2 \cdot 7 \pm 0.06 \\ 0-8 & 0.6 \pm 0.03\end{array}$

$0 \cdot 1-2 \cdot 2 \mathrm{~d} / \mathrm{m}^{226} \mathrm{Ra} / \mathrm{g}$ dry coral, while concentrations in samples from depths of $60 \mathrm{~m}$ were $2 \cdot 3 \mathrm{~d} / \mathrm{m}^{226} \mathrm{Ra} / \mathrm{g} \mathrm{dry}$ coral.

The greater concentrations at depth result from ingrowth of ${ }^{226} \mathrm{Ra}$ from the parent radionuclide, ${ }^{238} \mathrm{U}$. In addition the concentration of ${ }^{210} \mathrm{~Pb}$ in rainwater is approximately $5 \mathrm{~d} / \mathrm{m} / \mathrm{l}$. (refs. 10 and 11 ), and therefore a reasonable estimate of the naturally occurring ${ }^{210} \mathrm{~Pb}$ concentration in coraline soils is several $\mathrm{d} / \mathrm{m} / \mathrm{g}$ dry soil.

My results, Table 1 , show concentrations of ${ }^{210} \mathrm{~Pb}$ that do not exceed those expected to occur naturally. The ${ }^{226} \mathrm{R}$ a content of crater sediments and deep core samples should be about the same, as they are. Soils would be expected to contain concentrations of ${ }^{226} \mathrm{Ra}$ of $0 \cdot 1-2 \cdot 3$ $\mathrm{d} / \mathrm{m} / \mathrm{g}$ dry soil, depending on the depth sampled, the degree of equilibrium between ${ }^{226} \mathrm{Ra}$ and its parent, ${ }^{238} \mathrm{U}$, and the amount of particulate matter associated with the fallout; the latter is a mixture of coral from various depths and hence variable in ${ }^{226} \mathrm{Ra}$ content. Thomas ${ }^{12}$ reported the ${ }^{207} \mathrm{Bi}$ content of the crater sediment collected at Bokonejien Islet in 1967 as $200 \mathrm{~d} / \mathrm{m} / \mathrm{g}$ dry sediment. By contrast, the ${ }^{210} \mathrm{~Pb}$ content of the same sample is $3.3 \mathrm{~d} / \mathrm{m} / \mathrm{g}$ dry. If ${ }^{210} \mathrm{~Pb}$ had been produced in significant amounts during the testing programme, the concentrations in the crater sediments would be much greater than they are.

It seems unlikely that the US tests of $1958-59$ or $1961-62$ contributed significantly to the ${ }^{210} \mathrm{~Pb}$ content of the atmosphere. Production by USSR tests cannot be discounted due to differences in structural materials in and around the device, but the absence of any reported ${ }^{207} \mathrm{Bi}$ in worldwide fallout associated with these tests casts some doubt on this possibility.

I thank Professor E. E. Held for selecting the samples and for helpful discussions. This work was performed under contract between the US Atomic Energy Cornmission and the University of Washington.

\section{T. M. BEAsLFY}

University of Washington,

College of Fisheries,

Laboratory of Radiation Ecology,

Seattle 98105.

Received April 8; revised August 7, 1969.

1 Peirson, D. H., Cambray, R. S., and Spicer, G. S., Tellus, 18, 423 (1966).

2 Jaworowski, Z. S., Nature, 212, 886 (1966).

${ }^{3}$ Bhandari, N., Lal, D., and Rama, Tellus, 18, 391 (1966).

Crozaz, G., in Symp. Radioactive Dating and Methods of Lou-level Counting, 385 (Int. A tomic Energy Agency, Vienna, 1967).

Krey, P., Tech. Rep. HASL-207 (AEC Health and Safety Laboratory, New York, April, 1969).

'James, R. A., and Fleming, E. H., Tech. Rep. UCRL-50050-1 (Univ. California, Livermore, 1966).

7 Lowman, F. G., and Palumbo, R. F., Nature, 193, 796 (1962).

${ }^{8}$ Mauchline, J., and Templeton, W. L., Oceanog. Mar. Biol. Ann. Rev., 2 $229(1964)$.

${ }^{9}$ Broecker, W. S., J. Geophys. Res., 68, 2817 (1963).

${ }_{10}$ Burton, W. M., and Steward, N. G., Nature, 186, 584 (1960).

1 Patterson, R. L., and Lockhart, jun., L. B., in The Natural Radiation Environment, 383 (Univ. Chicago Press, Chicago, 1964).

${ }^{12}$ Thomas, C. W., Tech. Rep. PNWL-715, Part 2 (Paeiflc Northwest Laboratory, 1968). 